\title{
GENOTYPIC CONTROL OF CHROMOSOME BEHAVIOUR IN RYE. III. CHIASMA FREQUENCY IN HOMOZYGOTES AND HETEROZYGOTES
}

\author{
H. REES and J. B. THOMPSON \\ Agricultural Research Council Unit of Biometrical Genetics, \\ Department of Genetics, University of Birmingham \\ Received 24.i.56
}

\section{INTRODUCTION}

EARLIER work has shown that the average chiasma frequencies found in p.m.c. of rye plants are subject to the control of the genotype (Rees, I $955 a$ and $b$ ). It has also been established that the control is polygenic, except in rare cases where a single recessive gene may cause asynapsis (Prakken, 1943). Something of the nature of this polygenic control becomes evident from the results of inbreeding experiments which have been carried out in this species (Lamm, 1936; Müntzing and Akdik, 1948). Normal rye populations outbreed and hence comprise genotypes which are partially heterozygous. It was found that inbreeding led to a reduction in chiasma frequency, and often to failure of metaphase pairing. Efficient chiasma formation thus depends upon a genetic balance achieved through polygenes in partially heterozygous combinations. The experiment to be described was carried out to discover how such a system of genes operates. For this purpose a sample of homozygous inbred lines were crossed in a number of combinations and the results from parent lines and their $\mathrm{F}_{1}$ s have been analysed using, as far as possible, the techniques available for investigating continuous variation.

We are concerned with the effects of crossing homozygotes on two different aspects of the variation in chiasma frequency. In the first place we need to discover in what manner this affects the mean frequency of chiasmata in p.m.c. of different genotypes. In the second place we can investigate the environmental, non-heritable, variation in the chiasma frequency of p.m.c., and in particular we can compare the extent of such variation in homozygotes and heterozygotes. For studying this non-heritable component of variation chiasma frequency is a particularly useful character, because the variation can be measured at three levels (i) between plants of the same genotype. (ii) between p.m.c. within plants, and (iii) between bivalents within p.m.c. From such investigations we can hope to gain a better understanding of the genetic and physiological interrelations which govern the expression of chiasma frequency as a property of the nuclear phenotypes at meiosis.

\section{MATERIAL AND METHOD}

Chiasma frequency was scored in 20 p.m.c. in each plant, and from this scoring three metrics were derived :-

1. The plant chiasma frequency, which is expressed as the average per bivalent (cf. Rees, l.c.) of the 20 cells scored. 
2. The cell variance, which is the variance-with 19 degrees of freedombetween the p.m.c. in chiasma frequency per bivalent.

3. The bivalent variance, being the variance in chiasma frequency-with 120 degrees of freedom (there being seven bivalents, and therefore six comparisons, in each of the 20 p.m.c.)--between bivalents within p.m.c.

TABLE I

Plant chiasma frequencies, cell variances and bivalent variances in the inbred lines grown in 1954

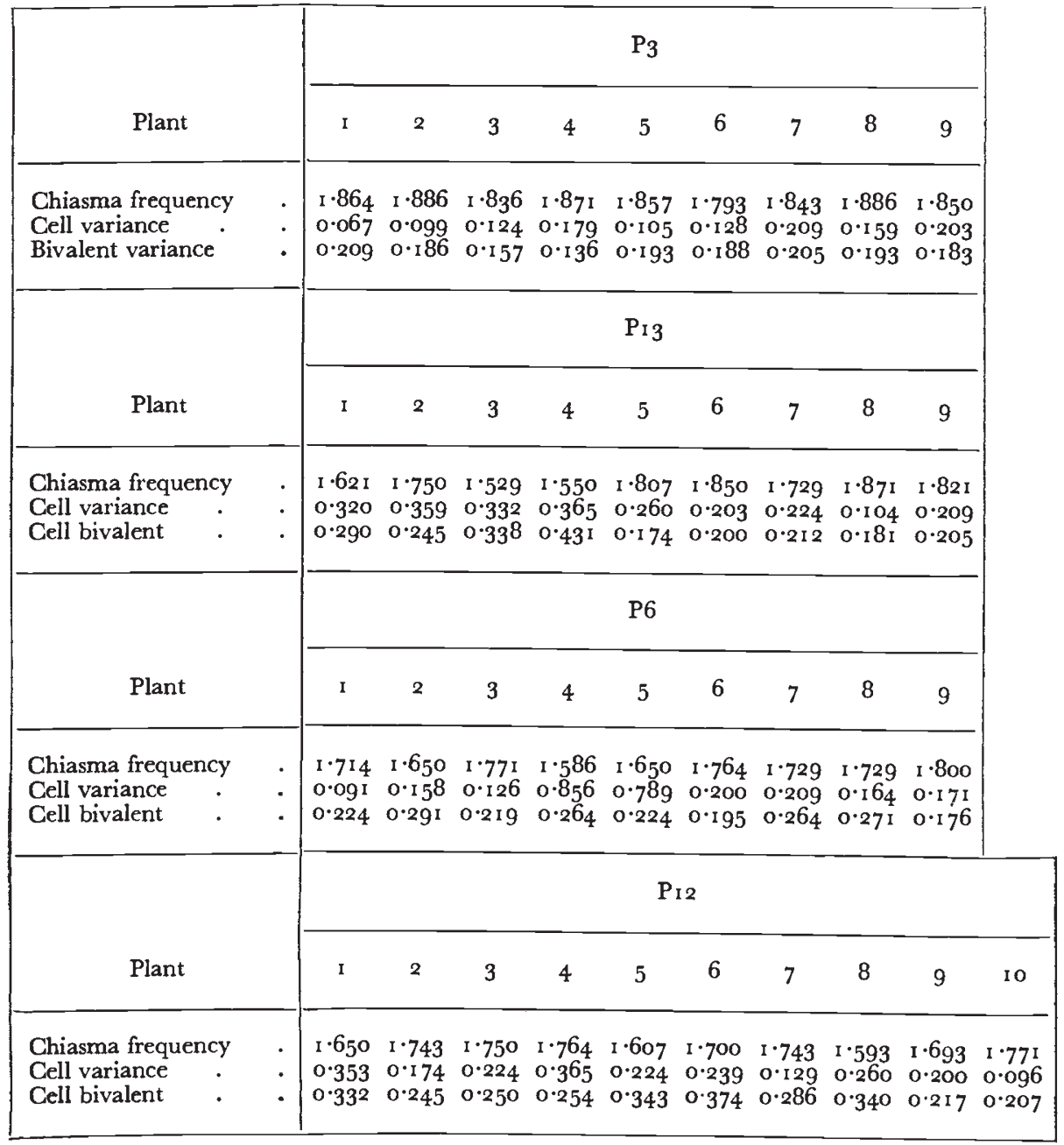

All means and variances for convenience are expressed in terms of the chiasma frequency per bivalent.

The lines have been inbred by self pollination for more than 20 generations and are assumed to be virtually homozygous. The four lines used in the diallel experiment to be described were crossed in all combinations to produce six $F_{1}$ families. Because of shortage the seed from reciprocal crosses was pooled and the plants scored without reference to the way in which the cross was made. 


\section{HETEROSIS}

The chiasma frequency distributions in the parent lines and their $F_{1} s$ are shown in tables $I$ and 2 and in fig. $I$. We may note in respect of the mean values of lines and $F_{1} s$ the following features :-

(I) The lines differ from one another $(\mathrm{P}=<0 \cdot 0 \mathrm{I})$.

\section{INBRED LINES}

$\begin{array}{ll}P_{3} & \bar{x}: 1.854 \\ P_{6} & \bar{x}: 1.710 \\ P 12 & \bar{x}: 1.701 \\ P 13 & \bar{x}: 1.725\end{array}$

$V: 0.0008$

$V: 0.0048$

$V: 0.0042$

$P 13 \quad \bar{x}: 1.725$

$V: 0.0167$

$$
\text { F1 }
$$
$3 \times 6$
$\bar{x}: 2.033$
$V: 0.0001$
$3 \times 12$
$\bar{x}: 2.072$
$V: 0.0012$

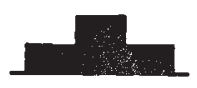
$3 \times 13 \quad \bar{x}: 2.086$
$V: 0.0001$

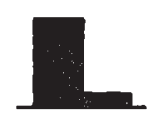
$6 \times 12 \quad \bar{x}: 2.044$
$V: 0.0007$

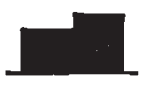
$6 \times 13$
$\bar{x}: 2.036$
$V: 0.0006$

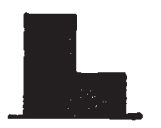
$12 \times 13 \quad \bar{x}: 2.069$
$V: 0.0005$

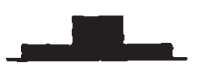
$\left[\begin{array}{l}5 \\ 0\end{array}\right.$

\begin{tabular}{lllllll}
$1: 5$ & 1.6 & 1.7 & 1.8 & 1.9 & 2.0 & 2.1 \\
\hline MEAN & XA. FREQ UENCY
\end{tabular}

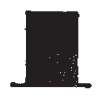

Frg. 1.-The distributions of plant chiasma frequencies in four inbred lines and their $F_{1}$ s. The $F_{1}$ families have higher means than the inbred lines. Means $(\bar{x})$ and variances (V) are listed. The vertical scale for the histograms is at the bottom, left. $\mathrm{Xa}=$ chiasma. 
(2) All $F_{1}$ s have higher means than the inbred lines $(P=<0 \cdot 001)$.

(3) The $\mathrm{F}_{1} \mathrm{~s}$ differ from one another $(\mathrm{P}=<0 \cdot 00 \mathrm{r})$.

TABLE 2

Plant chiasma frequencies, cell variances and bivalent variances in the $F_{1}$ families grown in 1954

\begin{tabular}{|c|c|c|c|c|c|c|c|c|c|c|c|}
\hline \multirow[b]{2}{*}{ Plant } & & \multicolumn{7}{|c|}{$3 \times 13$} & & & \\
\hline & & I & 2 & 3 & 4 & 5 & 6 & 7 & & & \\
\hline \multirow[t]{2}{*}{$\begin{array}{l}\text { Chiasma frequency } \\
\text { Cell variance } \\
\text { Bivalent variance }\end{array}$} & $:$ & $\begin{array}{l}2 \cdot 093 \\
0 \cdot 109 \\
0 \cdot 08 \mathrm{r}\end{array}$ & $\begin{array}{l}2 \cdot 071 \\
0 \cdot 038 \\
0 \cdot 13^{8}\end{array}$ & $\begin{array}{l}2 \cdot 107 \\
0 \cdot 073 \\
0 \cdot 217\end{array}$ & $\begin{array}{l}2 \cdot 086 \\
0 \cdot 111 \\
0 \cdot 140\end{array}$ & $\begin{array}{l}2 \cdot 086 \\
0 \cdot 051 \\
0 \cdot 100\end{array}$ & $\begin{array}{l}2 \cdot 079 \\
0 \cdot 052 \\
0 \cdot 093\end{array}$ & $\begin{array}{l}2 \cdot 086 \\
0 \cdot 08 \mathrm{I} \\
0 \cdot 095\end{array}$ & & & \\
\hline & & \multicolumn{10}{|c|}{$6 \times 13$} \\
\hline \multicolumn{2}{|l|}{ Plant } & I & 2 & 3 & 4 & 5 & 6 & 7 & 8 & 9 & 10 \\
\hline \multirow[t]{2}{*}{$\begin{array}{l}\text { Chiasma frequency } \\
\text { Cell variance } \\
\text { Bivalent variance }\end{array}$} & : & $\begin{array}{l}2 \cdot 043 \\
0 \cdot 047 \\
0 \cdot 057\end{array}$ & $\begin{array}{l}2 \cdot 029 \\
0.084 \\
0 \cdot 086\end{array}$ & $\begin{array}{l}2 \cdot 021 \\
0 \cdot 064 \\
0 \cdot 097\end{array}$ & $\begin{array}{l}2 \cdot 007 \\
0 \cdot 037 \\
0 \cdot 052\end{array}$ & $\begin{array}{l}2 \cdot 021 \\
0 \cdot 094 \\
0 \cdot 110\end{array}$ & $\begin{array}{l}2 \cdot 079 \\
0.067 \\
0.091\end{array}$ & $\begin{array}{l}2 \cdot 029 \\
0 \cdot 084 \\
0 \cdot 086\end{array}$ & $\begin{array}{l}2 \cdot 071 \\
0 \cdot 083 \\
0 \cdot 114\end{array}$ & $\begin{array}{l}2 \cdot 007 \\
0 \cdot 097 \\
0 \cdot 068\end{array}$ & $\begin{array}{l}2 \cdot 050 \\
0.245 \\
0 \cdot 167\end{array}$ \\
\hline & & & & $3 \times 6$ & & & & & $12 \times 13$ & & \\
\hline \multicolumn{2}{|l|}{ Plant } & I & 2 & 3 & 4 & 5 & I & 2 & 3 & 4 & 5 \\
\hline \multirow[t]{2}{*}{$\begin{array}{l}\text { Chiasma frequency } \\
\text { Cell variance } \\
\text { Bivalent variance }\end{array}$} & . & $\begin{array}{l}2 \cdot 043 \\
0 \cdot 122 \\
0 \cdot 145\end{array}$ & $\begin{array}{l}2 \cdot 036 \\
0 \cdot 118 \\
0 \cdot 138\end{array}$ & $\begin{array}{l}2 \cdot 043 \\
0 \cdot 167 \\
0 \cdot 105\end{array}$ & $\begin{array}{l}2 \cdot 014 \\
0 \cdot 104 \\
0 \cdot 167\end{array}$ & $\begin{array}{l}2 \cdot 029 \\
0 \cdot 144 \\
0 \cdot 109\end{array}$ & $\begin{array}{l}2 \cdot 071 \\
0 \cdot 218 \\
0 \cdot 143\end{array}$ & $\begin{array}{l}2 \cdot 050 \\
0 \cdot 094 \\
0 \cdot 090\end{array}$ & $\begin{array}{l}2 \cdot 100 \\
0 \cdot 122 \\
0 \cdot 169\end{array}$ & $\begin{array}{l}2 \cdot 043 \\
0 \cdot 092 \\
0 \cdot 200\end{array}$ & $\begin{array}{l}2 \cdot 079 \\
0 \cdot 097 \\
0 \cdot 102\end{array}$ \\
\hline & & \multicolumn{8}{|c|}{$3 \times 12$} & & \\
\hline Plant & & I & 2 & 3 & 4 & 5 & 6 & 7 & 8 & & \\
\hline $\begin{array}{l}\text { Chiasma frequency } \\
\text { Cell variance } \\
\text { Bivalent variance }\end{array}$ & 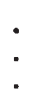 & $\begin{array}{l}2 \cdot 107 \\
0 \cdot 133 \\
0 \cdot 224\end{array}$ & $\begin{array}{l}2 \cdot 086 \\
0 \cdot 262 \\
0 \cdot 200\end{array}$ & $\begin{array}{l}2 \cdot 064 \\
0 \cdot 127 \\
0 \cdot 183\end{array}$ & $\begin{array}{l}2 \cdot 129 \\
0 \cdot 119 \\
0 \cdot 162\end{array}$ & $\begin{array}{l}2 \cdot 071 \\
0 \cdot 143 \\
0 \cdot 155\end{array}$ & $\begin{array}{l}2 \cdot 021 \\
0 \cdot 185 \\
0 \cdot 179\end{array}$ & $\begin{array}{l}2 \cdot 057 \\
0 \cdot 081 \\
0 \cdot 100\end{array}$ & $\begin{array}{l}2 \cdot 043 \\
0 \cdot 137 \\
0 \cdot 159\end{array}$ & & \\
\hline \multirow[b]{2}{*}{ Plant } & & \multicolumn{7}{|c|}{$6 \times 12$} & & & \\
\hline & & I & 2 & 3 & 4 & 5 & 6 & 7 & & & \\
\hline $\begin{array}{l}\text { Chiasma frequency } \\
\text { Cell variance } \\
\text { Bivalent variance }\end{array}$ & : & $\begin{array}{l}2 \cdot 007 \\
0 \cdot 143 \\
0 \cdot 102\end{array}$ & $\begin{array}{l}2 \cdot 036 \\
0 \cdot 164 \\
0 \cdot 148\end{array}$ & $\begin{array}{l}2 \cdot 086 \\
0 \cdot 217 \\
0 \cdot 191\end{array}$ & $\begin{array}{l}2 \cdot 050 \\
0 \cdot 185 \\
0 \cdot 143\end{array}$ & $\begin{array}{l}2.021 \\
0.125 \\
0.071\end{array}$ & $\begin{array}{l}2 \cdot 050 \\
0 \cdot 109 \\
0 \cdot 105\end{array}$ & $\begin{array}{l}2 \cdot 057 \\
0 \cdot 081 \\
0 \cdot 083\end{array}$ & & & \\
\hline
\end{tabular}

(I) evidently reflects genotypic differences between the lines which have been noted elsewhere (Rees, l.c.) and which need not be discussed further here.

(2) and (3) we need to consider in some detail. 
The higher values in heterozygous $F_{1}$ s clearly demonstrate heterosis for chiasma frequency. Since inbreeding in rye reduces the chiasma frequency and crossing inbred lines restores the higher values, it follows, as already pointed out, that in the $F_{1}$ hybrids and in population plants the high average chiasma frequency must depend on genetic balance in heterozygous genotypes. It will be seen, however, that, although all the $F_{1}$ s exhibit heterosis, particular heterozygotes express heterosis to different degrees: not all the heterozygous combinations are

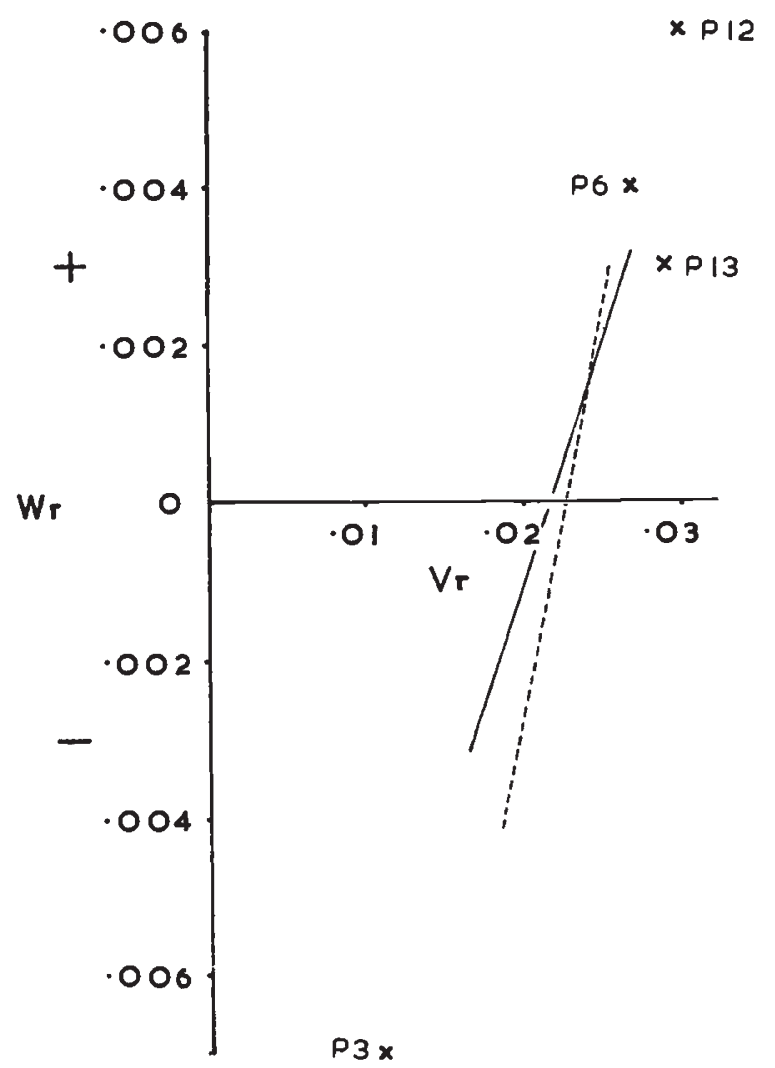

Fig. 2.-The covariance-variance graph of chiasma frequency in the diallel cross. The dotted line represents a slope of $\mathrm{r}$. Explanation in text.

balanced to the same extent either in the $F_{1} s$ above, or in population plants ( $c f$. Müntzing and Prakken, 194I).

The average efficiency of the population heterozygotes will evidently have been achieved under the influence of natural selection. We need now to inquire by what kind of gene interactions, allelic or non-allelic, such an efficiency is achieved and maintained. It is an important consideration because the answer would tell us how genetic recombination, through chiasma frequency, may be regulated in normal populations of outbreeding individuals.

Recently a method for detecting allelic and non-allelic interaction in diallel crosses of the kind we are dealing with has been developed 
by Jinks (1954) and Hayman (1954). The interactions are identified by plotting the variance of the offspring means $(\mathrm{Vr})$ against the covariance $(\mathrm{Wr})$ of the offspring family means with the means of the non-recurrent parents. This has been done with our data in fig. 2. The basis of interpreting the graph is described fully by the authors in the papers referred to above. The conclusions to be drawn from the graph are briefly :-

(i) There is high average "overdominance", since the regression line, which is significant, intersects the $\mathrm{Wr}$ axis below the origin. The order of average dominance is $\mathrm{P}_{3}, \mathrm{P}_{13}, \mathrm{P} 6$ and $\mathrm{P}_{12}, \mathrm{P}_{3}$ being the most dominant.

(ii) There is evidence of non-allelic interaction because the slope of the $\mathrm{Wr} / \mathrm{Vr}$ line is significantly different from I $(\mathrm{P}=$ $0 \cdot 05-0 \cdot 02)$.

It appears therefore that the apparent overdominance in mean chiasma frequency is at least partly due to non-allelic gene interaction, as indeed we might have expected on the basis of Jinks' analyses of heterosis involving a number of characters showing "overdominance" in a wide range of species (Jinks, I955).

\section{VARIATION WITHIN LINES AND $F_{1} s$}

The chiasma variation within the $F_{1} s$ and within the lines is between similar genotypes, so that we are here concerned with nonheritable differences. These differences arise through variation in uncontrolled environmental conditions under which the plants grow, though just what these variable conditions are is not easy to ascertain with any certainty. Weather changes from day to day are known to affect chiasma frequency (e.g. Mather, 1935), but in this instance such changes are of small importance, the effect of fixing on different days being insignificant. It is probable that the growth history of the plant over a long period may be reflected in the activities of the chromosomes at meiosis. There is for instance some evidence from another experiment that growing rye plants in different parts of the field may affect the chiasma frequency (Thompson, unpub.).

Whatever the factors causing the variation there is no doubt, as has been recently pointed out (Rees, $1955^{b}$ ) that the amount of variation between plants measured as the variance is much greater in the homozygous lines than in the heterozygous $F_{1} s$ (fig. I). This we have interpreted as reflecting the greater developmental stability, or homeostasis (see Lerner, 1954) of the heterozygotes in respect of chiasma frequencies.

Comparable proof of the greater stability of the heterozygotes is obtained when we consider the variation between cells within $F_{1}$ plants, and within inbred plants. The average variances are presented in table 3. Similarly when we consider the variation between bivalents 
within p.m.c. (table 4). Both between p.m.c. and within p.m.c. the variation is significantly greater $(\mathrm{P}=<0 \cdot 00 \mathrm{I})$ in the homozygotes.

While the distinction between heterozygotes and homozygotes is clear enough, high means and low variances, low means and high

TABLE 3

The average cell variances in the inbred lines and $F_{1}$ families

\begin{tabular}{|c|c|c|c|c|}
\hline & $\mathbf{P}_{3}$ & P6 & $P_{12}$ & $P_{13}$ \\
\hline $\begin{array}{l}\mathrm{P}_{3} \\
\mathrm{P}_{6} \\
\mathrm{P}_{12} \\
\mathrm{P}_{13}\end{array}$ & $O \cdot I \Psi^{I}$ & $\begin{array}{l}0.131 \\
0.307\end{array}$ & $\begin{array}{l}0 \cdot 148 \\
0 \cdot 146 \\
o \cdot 226\end{array}$ & $\begin{array}{l}0.074 \\
0.090 \\
0.125 \\
0.264\end{array}$ \\
\hline
\end{tabular}

variances respectively, there now arises the problem of the extent to which these variables are dependent upon each other. For example, does the degree of stability as measured by chiasma variation under a given range of growing conditions depend directly on the amount of

TABLE 4

The average bivalent variances in the inbred lines and the $F_{1}$ families

\begin{tabular}{|c|c|c|c|c|}
\hline & $\mathbf{P}_{3}$ & P6 & Pr2 & $P_{1}$ \\
\hline $\begin{array}{l}P_{3} \\
P_{6} \\
P_{12} \\
P_{13}\end{array}$ & $0 \cdot 18_{3}$ & $\begin{array}{l}0.133 \\
0.236\end{array}$ & $\begin{array}{l}0 \cdot 170 \\
0 \cdot 120 \\
0.285\end{array}$ & $\begin{array}{l}0.123 \\
0.093 \\
0.141 \\
0.253\end{array}$ \\
\hline
\end{tabular}

heterozygosity of the genotype ? Is it dependent to any extent on the mean chiasma frequency? We shall try to answer such questions in the following sections. At the same time it will be necessary to attempt to explain in physiological and genetical terms the basis for the variation between nuclei of identical genotypes.

\section{(i) Plant variation}

The variation in chiasma frequency between plants, as we have seen, is greater within the inbred lines than $F_{1}$ s. There are, however, considerable and highly significant differences between the amounts of variation in different lines. The Bartlett test of homogeneity of the variances, which are listed in fig. $\mathrm{I}$, gives a $\chi_{[3]}^{2}=15.57 \mathrm{I}(\mathrm{P}=$ $0.0 \mathrm{I}-0.00 \mathrm{I})$. Evidently this reflects genotypic diversity in respect of the stability properties of the inbred lines. Since the inbred lines are, virtually, homozygous this diversity cannot be related to varying degrees of hybridity. Neither are the line variances correlated, to 
any appreciable extent at least, with the mean chiasma frequencies : the regression of line means and line variances is not, in fact, significant (see below).

\begin{tabular}{|c|c|c|c|c|c|c|}
\hline \multicolumn{2}{|c|}{ Item } & SS & $\mathrm{N}$ & MS & VR & $\mathbf{P}$ \\
\hline Regression & . $\quad$. & 0.030197 & I & 0.030197 & $<\mathrm{r} \cdot \mathrm{O}$ & Not significant \\
\hline Error & . $\quad$. & 0.123103 & 2 & $0.06 r_{55^{1}}$ & $\ldots$ & $\ldots$ \\
\hline Total & . & $0 \cdot 153300$ & 3 & $\ldots$ & $\ldots$ & $\ldots$ \\
\hline
\end{tabular}

These observations have been confirmed in the data from the five inbred lines which were scored in 1952 (see Rees, 1955a). The data are given in table 5. Four of these lines were each represented by a pair of sub lines. The Bartlett test showed a significant difference in variances between lines $\left(\chi^{2}{ }_{[4]}=9.64 \mathrm{I}, \mathrm{P}=0.05-0.02\right)$ and no significant difference within lines, i.e. between sub lines $\left(\chi_{[4]}^{2}=2 \cdot 308\right.$, $\mathbf{P}=0 \cdot 70-0 \cdot 50)$. The regression between line means and line variances, as for the 1954 data, is not significant. The between plant variances for the six $F_{1}$ families are not significantly different.

Taking into account therefore the data from the two years it would appear that stability in the inbred lines, measured as the variation in chiasma frequency between plants, is determined by the particular homozygous genotypic combination. At the same time, while some homozygous genotypes show greater stability than others, generally they show less stability than the heterozygous $F_{1}$ s. Finally we have shown that this variation is, at least largely, independent of the mean chiasma frequency.

\section{(ii) Cell variation}

The distributions of cell variances (I954 data) are significantly different between inbred lines $(P=<0 \cdot 00 I)$. As for plant variation, it therefore appears that the amount of variation between p.m.c. in an anther is subject to the control of the genotype, and can vary between genotypes of equal hybridity.

This variation between the p.m.c. within a plant is not independent of the chiasma frequency. Within lines there is a strong and significant negative correlation between them (see table 1 ). Below is the joint regression analysis of variance which enables us to compare the

\begin{tabular}{|c|c|c|c|c|c|}
\hline Item & SS & $\mathrm{N}$ & MS & VR & $P$ \\
\hline $\begin{array}{l}\text { Joint regression } \\
\text { Heterogeneity of regressions } \\
\text { Heterogeneity of line means } \\
\quad(X \text { ta) } \\
\text { Error }\end{array}$ & $\begin{array}{l}0.5308 \\
0.56 \mathrm{ro} \\
1 \cdot 4005 \\
1 \cdot 0737\end{array}$ & $\begin{array}{r}1 \\
3 \\
3 \\
29\end{array}$ & $\begin{array}{l}0.5308 \\
0.1870 \\
0.4668 \\
0.0370\end{array}$ & $\begin{array}{r}14 \cdot 336 \\
5 \cdot 051 \\
12 \cdot 609 \\
\\
\quad \ldots\end{array}$ & $\begin{array}{c}<0 \cdot 001 \\
0.01-0.001 \\
<0.001 \\
\end{array}$ \\
\hline Total & $3.5^{660}$ & 36 & ... & ... & $\ldots$ \\
\hline
\end{tabular}


relationships between chiasma frequencies and cell variances in the four lines. The joint regression item is highly significant. It will

\section{TABLE 5}

Plant chiasma frequencies, cell variances and bivalent variances in five inbred lines grown in 1952. Four of the lines are each represented by a pair of sub-lines

\begin{tabular}{|c|c|c|c|c|c|c|c|c|c|c|c|}
\hline \multirow[b]{2}{*}{ Plant } & & \multicolumn{5}{|c|}{$\mathrm{P}_{2}$} & & & & & \\
\hline & & I & 2 & 3 & 4 & 5 & & & & & \\
\hline $\begin{array}{l}\text { Chiasma frequency } \\
\text { Cell variance } \\
\text { Bivalent variance }\end{array}$ & $\dot{.}$ & $\begin{array}{l}2 \cdot 043 \\
0 \cdot 393 \\
0 \cdot 269\end{array}$ & $\begin{array}{l}2 \cdot 079 \\
0 \cdot 263 \\
0 \cdot 360\end{array}$ & $\begin{array}{l}2 \cdot 043 \\
0 \cdot 33^{2} \\
0 \cdot 3^{12}\end{array}$ & $\begin{array}{l}2 \cdot 014 \\
0 \cdot 074 \\
0 \cdot 33^{8}\end{array}$ & $\begin{array}{l}1 \cdot 786 \\
0 \cdot 459 \\
0 \cdot 271\end{array}$ & & & & & \\
\hline \multirow{2}{*}{\multicolumn{2}{|c|}{ Plant }} & \multicolumn{5}{|c|}{$\mathbf{P}_{4}$} & \multicolumn{5}{|c|}{$\mathrm{P}_{5}$} \\
\hline & & I & 2 & 3 & 4 & 5 & I & 2 & 3 & 4 & 5 \\
\hline $\begin{array}{l}\text { Chiasma frequency } \\
\text { Cell variance } \\
\text { Bivalent variance }\end{array}$ & $\dot{:}$ & $\begin{array}{l}x \cdot 736 \\
0 \cdot 500 \\
0 \cdot 348\end{array}$ & $\begin{array}{l}1 \cdot 57 \text { I } \\
0 \cdot 57 \text { I } \\
0 \cdot 445\end{array}$ & $\begin{array}{l}1 \cdot 700 \\
0 \cdot 329 \\
0 \cdot 326\end{array}$ & $\begin{array}{l}I \cdot 450 \\
0 \cdot 485 \\
0 \cdot 3^{62}\end{array}$ & $\begin{array}{l}1 \cdot 786 \\
0 \cdot 218 \\
0 \cdot 312\end{array}$ & $\begin{array}{l}1 \cdot 414 \\
1 \cdot 35^{2} \\
0 \cdot 402\end{array}$ & $\begin{array}{l}1 \cdot 764 \\
0 \cdot 260 \\
0 \cdot 077\end{array}$ & $\begin{array}{l}1 \cdot 543 \\
0 \cdot 686 \\
0 \cdot 381\end{array}$ & $\begin{array}{l}I \cdot 686 \\
0 \cdot 445 \\
0 \cdot 264\end{array}$ & $\begin{array}{l}I \cdot 73^{6} \\
0 \cdot 500 \\
0 \cdot 28 \mathrm{I}\end{array}$ \\
\hline \multirow{2}{*}{\multicolumn{2}{|c|}{ Plant }} & \multicolumn{5}{|c|}{$\mathrm{P}_{7}$} & \multicolumn{5}{|c|}{ P8 } \\
\hline & & I & 2 & 3 & 4 & 5 & I & 2 & 3 & 4 & 5 \\
\hline $\begin{array}{l}\text { Chiasma frequency } \\
\text { Cell variance } \\
\text { Bivalent variance }\end{array}$ & $\dot{.}$ & $\begin{array}{l}1 \cdot 764 \\
0 \cdot 455 \\
0 \cdot 455\end{array}$ & $\begin{array}{l}x \cdot 764 \\
0 \cdot 230 \\
0 \cdot 474\end{array}$ & $\begin{array}{l}1 \cdot 779 \\
0 \cdot 413 \\
0 \cdot 436\end{array}$ & $\begin{array}{l}1 \cdot 743 \\
0 \cdot 490 \\
0 \cdot 529\end{array}$ & $\begin{array}{l}1 \cdot 871 \\
0 \cdot 224 \\
0 \cdot 329\end{array}$ & $\begin{array}{l}I \cdot 643 \\
0 \cdot 429 \\
0 \cdot 533\end{array}$ & $\begin{array}{l}I \cdot 721 \\
0 \cdot 458 \\
0 \cdot 429\end{array}$ & $\begin{array}{l}1 \cdot 67 \text { I } \\
0 \cdot 693 \\
0 \cdot 464\end{array}$ & $\begin{array}{l}\text { I } 829 \\
0 \cdot 250 \\
0 \cdot 376\end{array}$ & $\begin{array}{l}1 \cdot 729 \\
0 \cdot 420 \\
0 \cdot 364\end{array}$ \\
\hline \multirow{2}{*}{\multicolumn{2}{|c|}{ Plant }} & \multicolumn{5}{|c|}{$P_{13}$} & \multicolumn{5}{|c|}{$P_{14}$} \\
\hline & & I & 2 & 3 & 4 & 5 & I & 2 & 3 & 4 & 5 \\
\hline $\begin{array}{l}\text { Chiasma frequency } \\
\text { Cell variance } \\
\text { Bivalent variance }\end{array}$ & $\begin{array}{l}\dot{ } \\
\dot{ } \\
\dot{ }\end{array}$ & $\begin{array}{l}I \cdot 900 \\
0 \cdot 408 \\
0 \cdot 357\end{array}$ & $\begin{array}{l}1 \cdot 979 \\
0.455 \\
0.419\end{array}$ & $\begin{array}{l}I \cdot 914 \\
0 \cdot 217 \\
0 \cdot 374\end{array}$ & $\begin{array}{l}1 \cdot 879 \\
0.470 \\
0.450\end{array}$ & $\begin{array}{l}\text { I } 97 \text { I } \\
0 \cdot 220 \\
0 \cdot 43^{I}\end{array}$ & $\begin{array}{l}1 \cdot 864 \\
1 \cdot 398 \\
0 \cdot 357\end{array}$ & $\begin{array}{l}\mathrm{I} \cdot 900 \\
0 \cdot 393 \\
0 \cdot 276\end{array}$ & $\begin{array}{l}2 \cdot 036 \\
0 \cdot 254 \\
0 \cdot 250\end{array}$ & $\begin{array}{l}I \cdot 850 \\
0 \cdot 443 \\
0 \cdot 379\end{array}$ & $\begin{array}{l}I \cdot 957 \\
0 \cdot 317 \\
0 \cdot 314\end{array}$ \\
\hline \multirow{2}{*}{\multicolumn{2}{|c|}{ Plant }} & \multicolumn{5}{|c|}{$\operatorname{Pr}_{7}$} & \multicolumn{5}{|c|}{ Pr 8} \\
\hline & & I & 3 & 4 & 5 & 8 & I & 2 & 3 & 5 & 8 \\
\hline $\begin{array}{l}\text { Chiasma frequency } \\
\text { Cell variance } \\
\text { Bivalent variance }\end{array}$ & $\dot{b}$ & $\begin{array}{l}1 \cdot 679 \\
0 \cdot 284 \\
0 \cdot 310\end{array}$ & $\begin{array}{l}I \cdot 571 \\
0 \cdot 316 \\
0 \cdot 336\end{array}$ & $\begin{array}{l}1 \cdot 63^{6} \\
0 \cdot 248 \\
0 \cdot 33^{1}\end{array}$ & $\begin{array}{l}1 \cdot 714 \\
0 \cdot 301 \\
0 \cdot 391\end{array}$ & $\begin{array}{l}\text { I } \cdot 664 \\
0 \cdot 455 \\
0 \cdot 338\end{array}$ & $\begin{array}{l}1 \cdot 521 \\
0 \cdot 320 \\
0 \cdot 391\end{array}$ & $\begin{array}{l}1 \cdot 664 \\
0 \cdot 290 \\
0 \cdot 314\end{array}$ & $\begin{array}{l}1 \cdot 629 \\
0 \cdot 232 \\
0 \cdot 319\end{array}$ & $\begin{array}{l}I \cdot 643 \\
0 \cdot 278 \\
0 \cdot 291\end{array}$ & $\begin{array}{l}I \cdot 750 \\
0 \cdot 404 \\
0 \cdot 305\end{array}$ \\
\hline
\end{tabular}

also be observed that the sum of squares for heterogeneity is significant, which argues that although the lines show the same general physiological relationship between cell variation and chiasma frequency, 
the rate of change of one relative to the other is not the same for every line. This may justifiably be attributed to genotypic causes.

Analysis of the r 952 data gives the same results except that the sum of squares for heterogeneity of regressions was not quite significant $(\mathbf{P}=0 \cdot 2-0 \cdot 05)$.

The negative correlation between cell variances and plant chiasma frequencies within families suggests the possibility of a causal relationship between the two properties. We have in fact obtained good evidence for such a relationship from an investigation of the chiasma distributions of large numbers of p.m.c. of inbred plants. The

INBRED

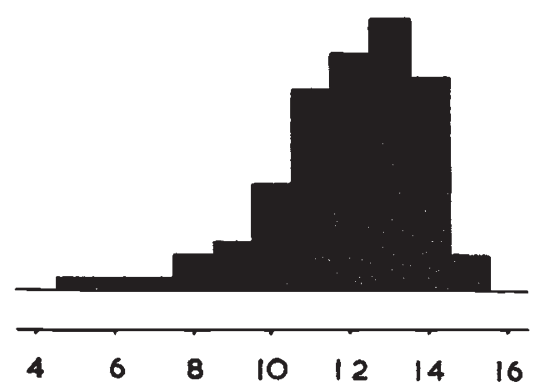

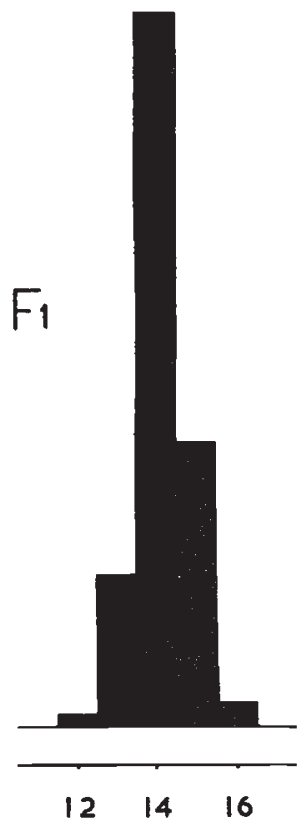

FIG. 3.-The distributions of chiasma frequencies in 100 p.m.c. in an inbred plant and in an $F_{1}$ plant. In the $F_{1}$ the mean is higher and the spread smaller. In the inbred plant the distribution is significantly skew. Chiasmata per cell on the horizontal scales.

distribution curves of chiasma frequencies of roo p.m.c. in each of nine plants from three lines were plotted. In general these curves show (I) a longer tail towards the lower values, and (2) a steep slope at the higher end (fig. 3). In three of the plants the skewness of the distributions is highly significant $(\mathrm{P}=<0.00 \mathrm{I})$.

These curves indicate a stricter limitation to the development of cells with high rather than with low frequencies. There is an upper limit in the number of chiasmata per cell ( $c f$. Mather, 1936). From these observations it would follow that an increase in variation arising within an anther is more likely to be in the direction of cells with fewer chiasmata; and so the greater the variation between cells the lower the plant chiasma frequency. In these inbred lines therefore a high degree of stability in development, as measured by cell variances 
results in a higher mean, and vice versa. We do not suggest that the amount of cell variation is the only factor affecting the plant chiasma frequency. Thus the regressions between the mean chiasma frequencies of lines and the mean cell variances of lines are not significant, either for the 1954 or 1952 data.

The relation found here between the degree of stability of body parts and mean values of character expression is not of course universal ( $c f$. asymmetry in flies, Mather, 1953). It depends in this instance on the upper limit imposed upon the expression of chiasma frequencies in the p.m.c.

In the $F_{1}$ families the chief difference from the inbred lines is that the cell variances are smaller (table 3 , fig. 3). As in the inbred lines ( $\mathrm{I}$ ) there are significant differences between families $(P=0.05$ $0.01)$, (2) there is no significant regression between the mean cell variances of families and the mean chiasma frequencies of families. In contrast to the inbred lines, however, we find the regression between cell variances and chiasma frequencies within families is not significant.

When we seek to explain the material basis for the variation between p.m.c. within an anther we can, as pointed out earlier, rule out variation in nuclear genotypes within it, since the nuclei must be genetically identical. The variation must result from differences arising outside the nuclei, in the cytoplasm, which affect their behaviour. These cytoplasmic differences are initiated no doubt by local environmental fluctuations within the anther. In those anthers where the cytoplasm is more resistant to qualitative changes, and therefore more uniform, under a given set of growing conditions the p.m.c. variation will be low and the average chiasma frequency consequently relatively high. Furthermore we conclude that since cell variation varies between lines and families the extent of this variation arising in the cytoplasm is under the influence of the genotype.

\section{(iii) Bivalent variation}

The distributions of bivalent variances within cells again are significantly different between the lines $(\mathbf{P}=<0.00 \mathrm{I})$. Within lines bivalent variances, like cell variances, are negatively correlated with the chiasma frequencies $(P=<0 \cdot 00 \mathrm{I})$. Between lines the regression between average variances and average chiasma frequencies is not significant. In the $\mathrm{F}_{1} \mathrm{~s}$ also the situation is much the same as for cell variances, (I) the bivalent variances are smaller (table 3), (2) the families show significant differences $(\mathrm{P}=0.0 \mathrm{I}-0.00 \mathrm{I})$, and (3) the regressions between chiasma frequencies and bivalent variances are not significant either within families or between family averages. It will be seen that differences in bivalent variances between genotypes (e.g. of inbred lines) can, like differences in cell variances, be independent of the degree of hybridity.

Many factors are known to affect variation in chiasma frequency between bivalents within p.m.c. ( $c f$. Darlington, 1937). These 
depend upon (I) genetic (including structural) differences between chromosome pairs, and (2) the cytoplasmic environment of p.m.c. nuclei before or during the early stages of meiosis. The latter may be modified by the genotype or by external conditions. A likely explanation for the genotypic differences in the present experiment has been suggested to us by Professor Darlington, viz. that the prepachytene pairing arrangement of homologous chromosomes within the nucleus may be less regular in some genotypes than in others. Such irregularity might even begin as early as the pre-meiotic telophase. Most probably the regularity in chromosome arrangement would depend on the cytoplasmic environment within the cell, and this would vary between genotypes. On this view arrangement would, in general, be irregular in homozygotes, regular in heterozygotes.

It was pointed out earlier that bivalent variances and chiasma frequencies are negatively correlated between plants within inbred lines. This has been shown in another way. Regressions were calculated between the twenty p.m.c. bivalent variances and chiasma frequencies scored within single anthers. The mean regression for eight inbred plants (two at random from each line) is significant $(\mathbf{P}=<0.001)$. This relation between the chiasma frequency and the bivalent variation in inbred lines is not surprising if, as suggested above, bivalent variation in the inbred plants results from irregularity in pairing arrangement : the more irregular the pairing the lower we should expect the chiasma frequency to be. Earlier it was postulated that chiasma variation between p.m.c. within an anther was due to cytoplasmic variation between the cells. It may reasonably be assumed this operates at least to some extent by influencing the pairing arrangements of the chromosomes.

The relation between bivalent variation and p.m.c. chiasma frequency is, however, by no means simple and direct. We find, for example, an entirely different situation within anthers of $F_{1}$ plants where regression analyses demonstrate a significant positive correlation between bivalent variances and p.m.c. chiasma frequencies. If pairing arrangements in $F_{1}$ p.m.c. are regular, other factors, such as genetic differences between bivalents, would be more clearly revealed, and may well be responsible for the variation.

\section{DIALLEL ANALYSES INVOLVING THE VARIANCES}

By comparing lines and families we have shown that developmental stability in respect of chiasmata, in whichever of the three ways we measured it, is strongly subject to genotypic control. An important question which then arises is whether stability measured at these three different levels is controlled by the same gene system. It is possible to gain information on this point by plotting $\mathrm{Wr} / \mathrm{Vr}$ graphs using the variances as our metrics. A comparison of these graphs will then show whether the inheritance is the same for each variance. The graphs are shown in fig. 4 . 
For plant variances the regression line, which is significant $(P=$ $0 \cdot 01-0 \cdot 001$ ) passes near to the origin and its slope is not significantly different from $\mathrm{I}$. There is thus no evidence for non-allelic interaction or for "overdominance". The order of average dominance is PI2, $\mathrm{P}_{3}, \mathrm{P} 6, \mathrm{P}_{13}$.

The $\mathrm{Wr} / \mathrm{Vr}$ regression line for cell variances, which is also significant, passes below the point of origin, indicating "overdominance". The slope $\left(b=0.55^{8}\right)$ is significantly different from I $(P=0.02-0.01)$,
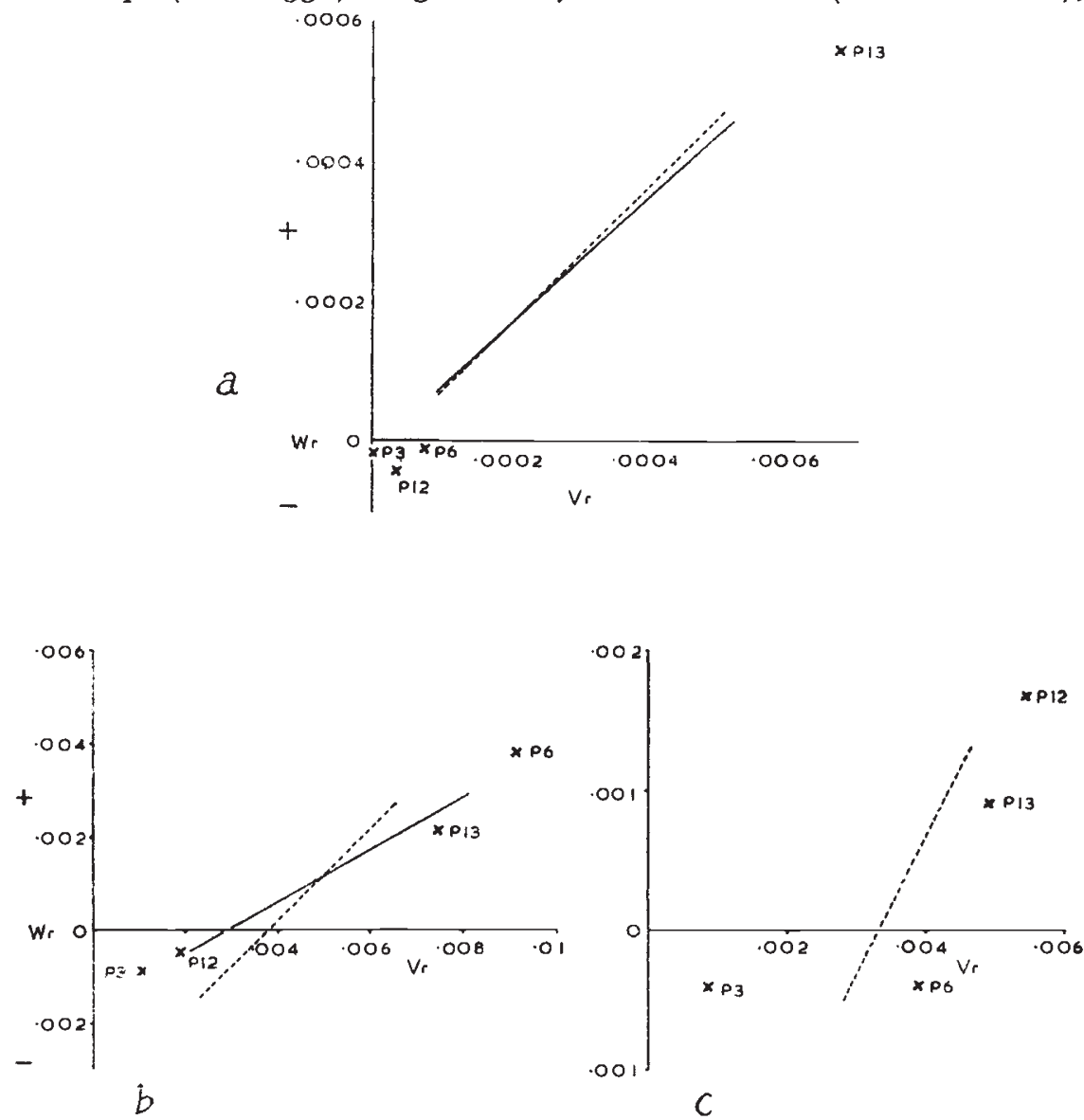

Fic. 4.-The covariance $(\mathrm{Wr})$-variance $(\mathrm{Vr})$ graphs of variances between $(a)$ plants, $(b)$ cells and $(c)$ bivalents in the diallel cross. The dotted line in each case represents a slope of $\mathrm{I}$, the solid line the $\mathrm{Wr}-\mathrm{Vr}$ regression. Explanation in text.

and therefore is evidence for non-allelic interaction. In both these respects the inheritance of cell variances is different from plant variances. In addition, the order of dominance is not the same, being $\mathrm{P}_{3}, \mathrm{P}_{12}, \mathrm{P}_{13}, \mathrm{P} 6$.

With regard to bivalent variances the $\mathrm{Wr} / \mathrm{Vr}$ line is not significant. This possibly may be accounted for by strong interaction in certain genotypes. Other causes, however, may be responsible and no definite conclusions can be drawn from the graph in respect of the inheritance 
of this property. We may note, however, that the order of dominance distinguishes it from the other two $\left(\mathrm{P}_{3}, \mathrm{P}_{6}, \mathrm{P}_{\mathbf{I}_{3}}, \mathrm{P}_{12}\right)$.

It is evident from these facts that chiasma variation at one level is not controlled in a way identical to that exercised at other levels. Indeed our evidence strongly indicates the control to be at least partly different for each variance.

It will also be seen that these graphs differ from that for mean chiasma frequency (fig. 2), either in slope or dominance relationships. This supports the earlier evidence, viz. the absence of significant regressions between mean chiasma frequencies and variances of inbred lines and $F_{1}$ families, that the variances can be at least partly independent of the mean in inheritance. The independence of mean and variances in inheritance is of course not incompatible with their physiological correlation. For example, it has been shown earlier that cell variances and chiasma frequencies are negatively correlated within lines by virtue of a more or less well defined " upper limit" to the number of chiasmata per cell. Despite this physiological relationship the mean can vary independently of the variance in different genotypes where, for instance, the "upper limits" are different.

\section{GENETIC RECOMBINATION AND NATURAL SELECTION}

In chiasma frequency the two main features that distinguish rye heterozygous genotypes from homozygotes are (I) the average per plant is higher, and (2) the variation between cells and bivalents within plants ( $c f$. Lamm, I936), and between plants of the same genotype, is smaller. The smaller variation in heterozygotes, within plants, and between plants of the same family, both reflect greater stability in development. It has been shown that, although this kind of variation is initiated by environmental fluctuations, the amount of variation exhibited depends on the particular genotype. Now heterozygous genotypes in general show less variation, i.e. show greater stability, than homozygotes. But it cannot be the degree of hybridity in itself which directly determines this, because inbred lines equally homozygous show different degrees of stability. This view agrees with the conclusions of Jinks and Mather (1955) based on evidence from Nicotiana rustica, a partial inbreeder, and from Drosophila melanogaster (Mather, 1954). It appears therefore, as these authors point out, that the high degree of developmental stability (associated in this case with rye heterozygotes) has been achieved by the action of natural selection for particular, balanced, genic combinations.

There is no doubt that plant chiasma frequencies, and hence the average amount of genetic recombination in a population is adjusted by natural selection, and thereby controls the release of variability in that population. We can now also see how the range of recombination values of gametes produced by the same genotype may be adjusted, 
and this to some extent at least independently of the mean frequency. First, the variation between p.m.c. within a plant can be controlled. Secondly, there can be control of the manner in which chiasmata are distributed between the bivalents within p.m.c. such that the chiasmata are more, or less, equally shared by the bivalents. Both adjustments within the anther would affect the variety of gametes produced. The mechanism of this control, we have suggested, acts via the cytoplasm. Since the amount of cell and bivalent variation is relatively small in heterozygotes, we conclude that a relative uniformity between gametes in respect of recombination is an adaptive feature of rye populations.

It must be noted that although we may regard the large degree of environmentally induced variation between plants, cells and bivalents in inbred genotypes as reflecting developmental instability, the very mechanism of this instability can be controlled in such a way as to regulate the recombination properties of a population. We may sum up by saying that genetic recombination is subject to the control of the genotype at three levels, the plant, the cell and the bivalent, at any of which the values are capable of adjustment by natural selection.

\section{SUMMARY}

1. Four inbred lines of rye were crossed in all combinations and the chiasma frequency was scored in the parent lines and the six $F_{1}$ families. The average chiasma frequencies are higher in the $F_{1}$ heterozygotes than in the homozygous lines: the $F_{1} s$ exhibit heterosis for chiasma frequency.

2. The inheritance of plant chiasma frequency shows apparent "overdominance" in $F_{1}$. This is in part at least explained by nonallelic interaction.

3. Analysis of environmentally induced variation, measured by comparisons within identical genotypes, gave the following results :

(I) There is less variation between plants within $F_{1}$ families than within inbred lines.

(2) There is less variation between p.m.c. and between bivalents within p.m.c. in heterozygotes than in homozygotes.

Thus, in respect of chiasma frequencies, under the conditions of the experiment the heterozygous genotypes show greater stability in development than the homozygotes.

4. Inbred lines equally homozygous differ in stability. Stability therefore is not simply related to the degree of hybridity of the genotype.

5. Stability, measured as the variation between plants, between cells and between bivalents is genotypically controlled; but the control is not the same for the variation shown at these three levels. The gene system controlling the mean plant chiasma frequency is also 
different, so that variances and means, to some extent at least, can show independence in inheritance.

6. It is postulated that variation in chiasma frequency between p.m.c. results from intercellular variation in the cytoplasm which influences chiasma formation. This cytoplasmic variation is much less in heterozygotes than in homozygotes. It also varies between inbred lines.

7. Within inbred lines chiasma frequencies are negatively correlated with cell variances. On our view this means that within an inbred line cytoplasmic variation between cells is greatest in plants with the lower chiasma frequencies.

8. It is also demonstrated that the chiasma frequency per cell in an inbred plant has an upper limit. An increase in cell variation therefore lowers the mean, and this explains the negative correlation.

9. Bivalent variances, like cell variances, are negatively correlated with chiasma frequencies within inbred lines. The bivalent variation and the correlation with chiasma frequency may, in part, be explained in terms of irregularity of pre-pachytene pairing.

Io. It is concluded that selective adjustment in chiasma frequency and hence in genetic recombination is possible at the three levels of plant, cell and bivalent.

Acknowledgments.-We are indebted to Professor K. Mather, Dr J. L. Jinks and Dr B. I. Hayman of this Unit, and to Professor C. D. Darlington, for their advice and criticism.

\section{REFERENCES}

DARLington, C. D. 1937. Recent Advances in Cytology. London, Churchill.

HAYMAN, B. 1. 1954. The theory and analysis of diallel crosses. Genetics, 39, 789-809. JINKs, J. L. 1954. The analysis of quantitative inheritance in a diallel cross of Nicotiana rustica varieties. Genetics, 39, 767-788.

JINKS, J. L. 1955. A survey of the genetical basis of heterosis in a variety of diallel crosses. Heredity, 9, 223-238.

JINKS, J. L., AND MATHER, K. 1955. Stability in development of heterozygotes and homozygotes. P.R.S., B, $143,561-578$.

LAMM, R. 1936. Cytological studies on inbred rye. Hereditas, 22, 21 7-240.

LERnER, 1. M. 1954. Genetic Homeostasis. Edinburgh, Oliver and Boyd.

MATHER, K. 1935. Chromosome behaviour in a triploid wheat hybrid. Z. Zellforsch., $23,119-138$.

MATHER, K. 1936. Competition between bivalents during chiasma formation. P.R.S., B, $120,208-227$.

MATHER, K. 1954. The genetic control of stability in development. Heredity, 7, 297-336.

MÜNTZING, A., AND AKDIK, s. 1948. Cytological disturbances in the first inbred generation of rye. Hereditas, 34, 485-509.

MÜNTZING, A., AND PRAKKEN, R. 1941. Chromosomal aberrations in rye populations. Hereditas, 27, 473-494.

PRAKKEN, R. 1943. Studies in asynapsis in rye. Hereditas, 29, 475-495.

REES, H. 1955a. Genotypic control of chromosome behaviour in rye. 1. Inbred lines. Heredity, 9, 93-1 16.

REES, 11. 1955b. Heterosis in chromosome behaviour. P.R.S., B, 144, 150-159. 